\title{
PLTSa vs Kesuksesan Bau Busuk
}

\author{
Oleh Gede H. Cahyana
}

Dosen Teknik Lingkungan, Universitas Kebangsaan, Bandung

Tidak ada satu teknologi pun, khususnya di bidang pengolahan sampah yang memberikan solusi tuntas. Ini berbeda dengan pengolahan air limbah yang relatif lebih mudah dan jauh lebih mudah lagi adalah pengolahan air baku (mata air, air tanah, air sungai/waduk, air laut) menjadi air minum. Sebab utamanya adalah variasi wujud zat, yaitu padat dan cair serta variasi jenis sampahnya. Dua kategori variasi ini yang menyulitkan dalam penerapan jenis teknologi yang aman bagi kesehatan manusia, efektif dalam pengolahannya dan tinggi efisiensi atau kinerjanya.

Oleh sebab itu, pendekatan sosiologi dan budaya menjadi hal utama, bukan sekadar pendukung. Prinsip 3R: reduce, reuse, recycle adalah pendekatan sosiobudaya dengan sentuhan teknologi sederhana dalam recycle. Masyarakat sebagai penimbul sampah diajak ikut berperan dalam pengelolaan (management) dan pengolahannya (treatment) dalam skala kecil seperti banyak dilakoni oleh saudara kita dari Madura. Bagi kelompok ini, sampah adalah "serpihan emas" yang dibuang. Bagi warga masyarakat lainnya, sampah adalah sumber daya yang dapat dijadikan pupuk dan produk olahan sekunder lainnya. Tas, sandal, sepatu, bahkan baju pun ada yang dibuat dari sampah atau bahan yang dianggap tak dibutuhkan lagi. Di sinilah peran pemulung yang ikut mereduksi volume dan berat sampah yang akan ditimbun di TPA.

Sampah lainnya, yaitu organik bisa dijadikan kompos dengan cara sederhana. Pengompos atau composter yang banyak dianjurkan adalah proses aerob. Kondisi aerob ini dapat meminimalkan bau busuk, apalagi kalau diletakkan di halaman rumah atau di sebuah sudut TPS di RT/RW. Bau busuk dari TPS inilah yang diprotes warga. Selain itu, lalat dan tikus sebagai vektor penyakit dapat menurunkan kesehatan warga sekitar. Bisa 
juga diterapkan proses anaerob, misalnya dengan membuat lubang di halaman rumah kemudian sampah organik dimasukkan dan diurug tipis dengan tanah setiap lima hari. Cara anaerob ini terutama yang skala RT/RW bisa menghasilkan bau busuk yang masif kalau tidak dilapisi tanah. Untuk menyiasatinya, sampah ini harus dijauhkan dari masyarakat sekaligus dimanfaatkan potensi energinya. Bisa dikatakan, tanpa bau busuk, tidak mungkinlah energinya dipanen. Hukum alamnya demikian. Di dalam bau busuk sampah tersimpan energi yang besar. Sebaliknya, di dalam kemudahan PLTSa, karena asal dibakar saja, tersimpan bencana besar.

Patut dicatat, PLTSa juga menebarkan bau busuk dari ceceran sampah di area sekitarnya dan dari sampah yang menunggu giliran dimasukkan ke dalam tungku. Terlebih lagi lokasinya di dalam/pinggir kota, bukan di luar kota (remote area). Tetapi sayang, bau busuk selama 24 jam per hari ini tidak bisa dimanfaatkan sebagai sumber energi. Sebab, energi dari PLTSa ini akan dihasilkan setelah sampah kering (sampah basah dikeringkan dulu) dibakar kemudian panas yang dihasilkannya digunakan untuk menguapkan air dan membangkitkan generator listrik (power plant). Ini berbeda dengan TPA sanitary landfill (sanfil) yang menggunakan kebusukan sampah sebagai sumber energi. Sanfil serupa dengan pengomposan anaerob. Sumber energinya adalah metana yang konsentrasinya bisa mencapai 50\% landfill gas (LFG). Sisanya karbondioksida dan gas yang menimbulkan bau busuk seperti H2S, NH3, dll.

Pemerintah dapat memanfaatkan metana ini sebagai sumber energi dan bisa dijual ke masyarakat atau industri atau digunakan untuk kebutuhan internal TPA. Bisa dikatakan, $L F G$ to energy ini akan ekonomis pada kisaran satu juta ton sampah. Kota Bandung dengan penduduk 2,5 juta orang dan asumsi timbulan sampah 2,5 liter per orang per hari, maka jumlahnya menjadi $6.250 \mathrm{~m} 3 /$ hari. Apabila berat jenis sampah 0,3 maka diperoleh 1.875 ton per hari. Dalam setahun 684.375 ton. Untuk mencapai 1 juta ton, dibutuhkan waktu 1,5 tahun. Dengan pertimbangan jenis sampah anorganik, maka diperkirakan satu juta ton sampah organik bisa dicapai dalam waktu 2 s.d 2,5 tahun. Menurut Joe Constance di dalam The Rotten Smell of Success (1997), setiap pound 
sampah yang didekomposisi menghasilkan 4,5 cubic feet gas (LFG) dan bisa berlangsung selama 30 tahun, jauh lebih lama daripada lifetime PLTSa. Ketika PLTSa hanya memberikan solusi parsial karena tidak bisa membakar 100\% sampah Bandung, sanfil justru bisa menerima semuanya.

Kesimpulan, setiap teknologi ada positif dan negatifnya. Yang dipilih adalah yang manfaatnya lebih banyak daripada mudaratnya alias ramah lingkungan, sesuai dengan amanat pasal 28 ayat (1) huruf d Peraturan Daerah Kota Bandung nomor 09 tahun 2011 tentang Pengelolaan Sampah. Menurut pasal tersebut, sanitary landfill akan ramah lingkungan justru dengan memanen gasnya yang berbau busuk (rotten smell) menjadi listrik. Sebaliknya PLTSa, ia akan menimbulkan gas berbahaya dan beracun di antaranya dioksin dan abu (fly ash) yang tersebar luas di langit cekungan Bandung.

Dampak ekologis inilah yang harus dipertimbangkan bukan praktik tender PLTSa yang dipertanyakan oleh KPPU (Komisi Pengawas Persaingan Usaha). Kejadian ini, seperti kata sejumlah akademisi dan LSM di Bandung, kian meyakinkan warga bahwa PLTSa adalah sekadar bisnis semata tanpa peduli pada ancaman bahayanya. Masyarakat Bandung berharap, semoga tidak demikian. *** 